\title{
The Sports Law in the Context of the Plurality of Law Systems and the New Concept of Professional Sport Work in European Area
}

\author{
Ph.D candidate: Saimir Shatku \\ Department of Civil Law, Faculty of law, University of Tirana \& \\ Department of Organizations and Management, \\ Faculty of Movement Sciences, Sports University of Tirana, Albania \\ E-mail: s_shatku@yahoo.com \\ Msc. Blerina Mema \\ Department of Organizations and Management, Faculty of Movement Sciences, \\ Sports University of Tirana, Albania \\ Prof. Dr. Kudret Çela \\ Department of Civil Law, Faculty of law, University of Tirana
}

Doi:10.5901/ajis.2014.v3n1p359

\section{Abstract}

In our social system is getting more and more ground to the role of law in general, but also sports and legal norms in particular the establishment, functioning and legitimacy of sports activities, clubs and sports federations. Seen in the context of a myriad of norms, rules and laws of our country whether, but European legal framework have given the developmental approach and institutional self-regulating principles of sports bodies as special public entity Sports which means that they are: sports subjects of law, not state, created by law in the public interest involved here (University of sport; Societies sports associations, sports clubs and federations) that whether a legal person in public stage or private have functional independence, political, economic, and executive decision to each organ. Purpose of this study in to show needs, practices and challenges to present legislation on a whole, as a package of legal-important character with sports, to identify schemes which function playgrounds, plant and sporting rights and obligations of plants administrators sports.

Keyword: Sports work contract, Legislative Techniques of Sport Law, Global Sports Law and lex sportive, Wada, Sports Ethical Code, Plurality Principles of Sports Law.

\section{Introduction}

As we all know the functioning of life in a proper way is also connected to the implementation of the laws that are regulated and approved by the legal bodies and governments around the globe. Every field has its laws and also sport cannot function unless there are laws.

Sport is the body of legal issues at work in the world of both amateur and professional sports. Even if Sports is exercised not officially but as amateur it has its laws so it can be regulated in a proper and functional way. Sports law overlaps substantially with the labor law, contract law competition or antitrust law. Sport apart other has also many ethical issues and rules which makes it as a subject more attractive. Issues like defamations and privacy rights are also an integral aspect of the sport law.

Sport is global everywhere there you can find it and this has influenced also in the focus of its legal regulation increasingly onto international sport federations. These organizations control and govern mostly the sport internationally. They have established laws how to rule the sports and also constitutions. They have the power and ability to take the decision which can have a profound effect on the career of players and that has important economic consequences. Mostly they are autonomous organization and independent of national governments. In a different way compared to other NGO's they claim immunity from legal proceedings. Many people around the world see sport as the main entertainment of their life being the fans of it. The feeling of sports around the people is strong so to be in a level of high attraction it should function in a fairway. 


\section{Methodology}

Explain how you have collected the material, which databases you have search and how you have included them with the criteria

It has been used Jabref program for the referred downloads articles by using Medline database followed by keywords like: Sport Law, Legislative Techniques of Sport Law, Sports center, Sports European Cards, Sports Ethical Code, Plurality Principles of Sports Law, European charter sports, European social code;

In this essay we are going to analyze the importance of the sport law in a plurality system. We are going to explain why the law is so important in the sport and how it is the national and plurality system of the sport law. How is the law treated and evaluated in its importance and efficiency in the world of the sport and what role does the law plays to make sport more attractive.

\section{Supremacy of International Law over National Law in the Sport's Area}

Initially it is necessarily to distinguish between the concepts of "international" and global sports law. In a generally manner International law deals with the relations between nations states not so identically the international sport law therefore can be defined as the principle of international law applicable to sport. [Nafzinger, (1999)], has argued that "as an authoritative process of decision making and legal discipline, international sport law is a much matter of international law as of sports law". He clearly sees it as aspect of international law. According to him one of the chief aspects of international sport law is that it uses the jus commune that is the general principle of international law. It is to be mentioned that the international sport law is wider than those principle that can be deduced from public international law alone and include additional rule of law safeguards that are significant in the rule of the sport. The main laws that are included can be such as fair hearings in disciplinary proceedings, no arbitrary or irrational decision, and impartial decision making. These are general legal principles that can be deduced from the judgments of national courts in sports in law cases.

In a general point of view international sporting federation cannot be regulated by national courts or governments. They can only be self-regulated by their own internal institutions or by external institution created or validated by them. Otherwise they enjoy diplomatic type immunity from legal regulation.

The distinction between international and global sport law reproduces differences between model of internationalized and globalized sport as developed by Houlian, 1991. He argues that "Internationalized sport" is often funded by state subsidy and has national framework of regulation. "Globalized sport" by contrast has nationally ambiguous or rootless teams sport without a state as in professional road cycling or formula. One motor racing where teams named after corporate sponsors, but it is to be said that Globalized sport has a uniform pattern of sport that diminishes national traditions and local diversity.

Globalized sport would be typified by minimal regulation or a pattern of self-regulation which under conditions or internationals sport national of regional (EU/European Union) system of licensing, certification and training would produce a mosaic of distinctive regulatory system and patterns "good governance"

In the first instance the global dimension of sport is regulatory and it embraces the whole complex of norms produced and implemented by the regulatory of sports regime. These rules are included and approved by different court regimes such as IOC International Olympic committee and International Federation (Ifs but also hybrid public private norms approved by the World Anti-Doping Agency. Regarding what it contains sport law is not simply transitional but actually global. The law of sport has also inside it the separation of powers in (particular quasi-judicial) with a strategic role played by the court of Arbitration of sport.

In these contests the formula "global sports law" thus covers all definitions so far provided by legal scholarship (such as lex sportive or International sport law) However the analysis of the global sport legal order therefore allows us to shed light on broader global governance trends affecting for example the institutional design of global regimes with specific regard to separation of powers and the emergency of judicial activities.

In specific cases which can clarify the role of the law in sport it can be mentioned that in the early judgment of the European court of justice which dealt with the free movement of players within the European community marked a milestone for the sport law: [Arnaut J.L.(2006)]. The decision (the "Bosman Case") limited the autonomy of international sport orders, affirmed the supremacy of EC law over sports rules and cast serious doubts on the legal theories thus far applied in the sport context.

The case took five years to be settled as each ruling was appealed; finally it reached the European Court of Justice 
in Luxemburg. Bosman sued on grounds of restraint of trade and argued that FIFAs Article 17 breached this and was in fact illegal. The court ruled in favour of Bosman as the system, as it was constituted, placed a restraint on freedom of movement of workers and was prohibited by Article 39 of the EU treaty of Rome [Chaker, A.-N.(2004)]. As a result the European Union demanded that regulations concerning players' transfers and limitations on foreign players be amended almost immediately [B. Kingsbury (2005)].

This ruling meant Bosman and every other EU footballer were free to negotiate deals to any other EU based team after their current contracts expired, they were also allowed to sign pre-contract deals with other clubs if they had six months remaining on their current deals. This ruling also stopped UEFA imposing quotas on how many foreign players are allowed to play in a team at any one time. At the time UEFA were imposing a quota on their European Cup competitions that only allowed three non-nationals in a team on match days. However these quotas were not fully outlawed, it could not be used to restrict the amount of non EU players on a match day team.

The Bosman case made a big change in the world of the football sport. The team which won a big competition affected by the benefit of the Bosman case was Manchester United who won the champion league in 1999 having almost 7 Non English players in the field.

In the twenty years that followed, the points of interaction between sports law, international law and national legal system have increased enormously to the extent that they have become innumerable and multifaceted: regulatory institutional procedural, and judicial. Every branch of law must deal with sport related issues, which arise in a most diverse range of fields: from antitrust regulation to commercialization of radio television broadcasting rights from labor disputes to human rights. As one of several examples we can take the legislative acts approved by state for hosting international sporting events. [M. Cuccia, (2000)] National laws "observe "the system of norms produced by international sporting institutions, and States comply with the provision within the foundational documents of the latter. Mostly national norms make reference to the Olympic charter which in some case is even incorporated into domestic legislation.

However Sport rules are genuine "global law" because they reach across the entire world, involve both international and domestic levels, and directly affects individuals (such as Athletes) this is for example the case of the Olympic charter a private act with which all states comply or of the above mentioned World anti -doping code a document that provides the framework for harmonization and anti - doping policies, rules, and regulation within sports organizations and among public authorities. [Shatku, S. Mema, B. Vinciguerra, Vinciguerra, S. (2013)]

In all these recent years sport has thus generated a set of institutions and rules that amounts to an autonomous legal corpus, which legal scholarship has varyingly referred to as "International Sport law" Global Sports Law and lex sportive thus drawing a patent analogy with the lex mercatoria governing international trade)

It is to be stressed that recently in many private regimes the role of international and national public authorities has recently begun to expand. From EU and the states in particular it started to increase the pressure in sport institution. Other than the Olympic movement governed by the IOC and the technical sport regimes of the individual legal orders regulated by Ifs new international sport regimes have emerged in which public authorities play a key role: examples are the world anti-doping led by WADA and having national terminals that in the majority of cases are public administrative bodies or the regime governing the organization of Olympic.

Therefore although the notions of "regimes and network are taken from other fields of scholarly they appear nevertheless to be extremely useful for understanding most of the legal relationship between the various international sport institutions and between these institution and national bodies. But for Historical political socio economic reasonssport unlike other regimes or networks displays a much advanced degree of legal and institutional development.

If sports legal orders can be usefully framed within the theory of regimes networks and systems, the foregoing analysis shows that an approach based on public and administrative law may even be more fruitful. There are several analogies between the activities undertaken by international sporting institutions and public authorities. In many cases similarly to what occurs today in other international regimes States are directly involved (as in the case of WADA) and the national bodies within the sport system are mostly of public nature.

In my view an administrative law perspective appears better equipped to deal with supranational phenomena than on based on the notion of "legal order" Italian legal scholarship has applied this notion to sport since 1920 because inter alia sport is an excellent subject for a case study, since all the feature of a "legal order" can be traced: these features identified by Massimo Severo Giannini elaborating the hypothesis originally conceived by Santi-Romanao are plurality addresses organization and norms.

This is why a perspective based exclusively on legal order theory may not be the most appropriate for explaining global sport law exhaustively. The sport system can therefore be appropriately analyzed by integrating such perspective with other approaches taken from international and administrative law. 
On a national level the domestic terminals of international sports regime are often regulated by public law. From this point of view the case of doping control measures offers a prime example because the establishment of WADA and the adoption of World anti - doping Code led to the creation of a uniform regulatory system and at the same time of a defense network of national bodies mainly of public nature.

Among other the sport has also the ethical principles which are very important. This can be called as a second distinctive type of rules governs in the field of sport. This can also be called as equitable principle which can be seen in the general purpose offence that exist in most association sporting rules of "bringing sport into disrepute "or some similarly formula.

For those reasons many international sport federation are trying to bring their own sphere of regulation as the moral principles that they see as very effectual in the area of sports. As one the key main element in this we can mention honesty and integrity of sport by not making barging in fixing the results. The fixing of results has caused especially a lot of worries and concern especially in the football. Betting scandals have brought a lot of problems to FIFA. Many strong measures have been taken and strongly laws should be abide to prevent this disastrous phenomenon for the world of sport

\section{Conclusions, Implications and Limitations}

It is clear that the sport law is very important for its further development and keeping it as the most attractive thing in the people's life. The main thing is sport are rules that make it so important but the laws also have it determinant part in the sport.

If there were no laws and rules in sport then there really wouldn't be anything. Rules bring order and fairness, without rules there would be chaos and sport wouldn't be a real game; just a bunch of people doing their own thing with no goal or point. The game would actually be boring without rules. Rules are very important for anything because they make things more interesting and managed. If there were no rules in sports, then they would become boring because nobody would understand that what is going on or what not. Rules are actually defined what the game is!!

If nor rules existed at all, one for example can use boxing gloves another may use cricket balls and another player might just round around beating people up. It is the rule what actually tells us what is sport in reality.

Sport has laws and rules so everyone can play fear and there can be winner and loser, each of which conditions teach valuable life lessons for all. Without rules the games would have no structure.

In the assessment of all mention above we can clearly have a conclusion that law in the sport is so important as in all other fields. If the law would not have been applied to the sport with the same weights as to all other fields sport would never have been so popular.

Having completed we can say that:

- Sports law, not only in its written form and approved by the respective parliaments can make legislation based on sport, but the unwritten laws that impose rules on sports fields as customs, traditions, and legal opinions or opinions sport having some sound base of a sport.

- Should the close collaboration between the clubs and sports federations that they unison to build a regular legal framework to serve European sporting events, international and national being.

\section{References}

Arnaut, J.-L. (2006). "Independent European Sport Review",UK Presidency of the EU, $200 S$.

Bousigue, A. (2008). "Le sport dans la politique de la RPC vis-a-vis des Etats-Unis: Quel role? 1949-1984", unpublished thesis for Sciences Po Lyon (France).

B. Kingsbury (2005). The Emergency of Administrative law 68 Law and contemporary Problems.

F. Ost. M. van de Kerchove De la piramdie ou reseau Pour un theorie dialectoque du droit Bruxelle.

Carny, J., Clissens, L., Madella, A. \& Pilkington, A. (2004). "Improving employment in the field of sport in Europe through vocational training", Vocasport project, Education and Culture DG, Brussels.

Chaker, A.-N. (1999). "Study of national sports legislation in Europe", Council of Europe Publishing, Strasbourg.

Chaker, A.-N. (2004). "Good governance in sport. A European survey", Council of Europe Publishing, Strasbourg.

Chappelet, J.-L. (2008). "The International Olympic Committee and the Olympic System. The governance of world sport", Routledge, London.

M. Beloff, T. Kerry \& M. Demetrius,(1999), Law Sports.

M. Coccia, (2000). Il controllo di piu societa sportiva tra conflitto di interessi e diritto antitrust, Rivista dir. sport. pg. 23;

Kaufmann-Kehler, G. et al (2003). "Legal Opinion on the Conformity of Certain Provisions of the Draft World AntDoping Code with Commonly Accepted Principles of International Law" February. Available at www.wadaama.org

Shatku-Mema, V. et al (2013). Review Article, Journal of Physical Activity \& Sports, 2013 Volume 1 Issue 1. 